\title{
Meningkatkan Potensi Diri Masyarakat Melalui Program Unggulan Bidang Pendidikan, Sosial, Agama dan Kesehatan pada Masa Pandemi Covid-19 di Desa Air Merah
}

\author{
Faisal Afandi Rambe ${ }^{1 *}$, Gusti Romanda², Lismayani Siregar ${ }^{3}$, Muhammad \\ |qbal $^{4}$ \\ ${ }^{1}$ Universitas Islam Negeri Sumatera Utara Medan, Indonesia \\ ${ }^{2}$ Universitas Islam Negeri Sumatera Utara Medan, Indonesia \\ ${ }^{3}$ Universitas Islam Negeri Sumatera Utara Medan, Indonesia \\ ${ }^{4}$ Universitas Islam Negeri Sumatera Utara Medan, Indonesia \\ * Corresponding Author. E-mail: ${ }^{1}$ faisalarambe@gmail.com
}

Receive: 03/02/2021

Accepted: 20/02/2021

Published: 01/03/2021

\begin{abstract}
Abstrak
KKN adalah Kuliah Kerja Nyata yang berarti wujud dari sebuah kegiatan pengabdian masyarakat yang dimana mahasiswa harus mengabdikan diri dengan sepenuh hati dilakukan dengan menggunakan pendekatan di lingkungan masyarakat yang ditentukan oleh pihak universitas pada daerah dan waktu tertentu serta pengelompokan yang ditentukan oleh pihak LP2M, manfaatnya yaitu untuk memperkenalkan aspek-aspek pendidikan, sosial, agama dan kesehatan. Dengan adanya KKN yang bertema Kembali Ke Desa, Benahi Desa, Perspektif beragama Dan Wahdatul Ulum. Dengan demikian diharapkan kepada mahasiswa agar mampu mengoptimalisasikan sebuah bentuk dari keluarga dalam menciptakan karakter Mahasiswa menjadi keluarga yang mampu menciptakan kekeluargaan yang sejahtera. Dan tentunya mampu menghadapi masalah yang terjadi pada masa krisis serta bersifat mandiri serta mampu berpikir kritis dalam menghadapi tantangan dalam kehidupan yang lebih nyata. Sebuah program yang berhasil dilaksanakan diantaranya pada program pendidikan seperti halnya kegiatan bimbingan belajar, pengenalan IT kepada anak SMP, dan pojok baca pada anak SD. Pada bidang sosial yaitu menjalankan program gorong royong, pembagian sembako kepada masyarakat yang kurang mampu. Pada bidang kesehatan melakukan sosialisasi proses dan pentingnya vaksinasi, Posyandu lansia, serta bagi bagi masker pada Masyarakat desa Air Merah. Pada bidang agama yaitu wirid, takziah, seminar moderasi beragama dan belajar mengaji. Serta sukses dalam bidang keagamaan dan keislaman yang dituangkan dalam GEBER SUBUH (Gerakan Berjamaah Subuh) serta tausiah agama. Adapun kendala yang paling utama yang terjadi yaitu masih ada masyarakat yang tidak turut berpartisipasi.
\end{abstract}

Kata Kunci: Mahasiswa, Kuliah Kerja Nyata (KKN), Pendidikan, Sosial, Agama, Kesehatan

Increasing Community Potential Through Excellent Education, Social, Religion and Health Sector Programs during the Covid-19 Pandemic in Air Merah Village

Abstract

KKN is a Real Work Lecture which means the form of a community service activity where students must devote themselves wholeheartedly using an approach in the community determined by the university at a certain area and time and groupings determined by LP2M, the benefits are to introduce aspects of education, social, religion and health. With the KKN with the theme of Returning to the Village, Fixing the Village, Religious Perspectives and Wahdatul Ulum. Thus, it is hoped that students will be able to optimize a form of family in creating student character to become a family that is able to create a prosperous family. And of course able to deal with problems that occur during a crisis and be independent and able to think critically in facing challenges in a more real life. A program that has been successfully implemented includes educational programs such as tutoring activities, introduction of IT to junior high school students, and reading corners for elementary school children. In the social sector, namely running a mutual cooperation program, distributing basic necessities to the poor. In the health sector, socializing the process and importance of vaccination, Posyandu for the elderly, and distributing masks to the Air Merah village community. In the field of religion, namely wirid, takziah, seminars on religious moderation and learning the Koran. As well as success in the fields of religion and Islam as outlined in the GEBER SUBUH (Subuh Congregational Movement) and religious tausiah. The main obstacle that occurs is that there are still people who do not participate.

Keywords: Student, Real Work Lecture (KKN), Education, Social, Religion, Health. 


\section{Pendahuluan}

KKN atau biasa disebut dengan kuliah kerja nyata berarti suatu aktivitas didalam perkuliahan yang dilakukan oleh mahasiswa KKN 187 dalam wujud melakukan pengabdian masyarakat pada suatu wilayah tertentu, kegunaannya yaitu membantu dalam menambahkan wawasan serta cara dalam menyelesaikan permasalahan di lingkungan masyarakat itu sendiri. KKN dapat diartikan sebagai sebuah proses dimana mahasiswa harus mampu menyelesaikan permasalahan.

$$
\text { Setiap mahasiswa memiliki }
$$

kesempatan serta sudah menjadi kewajiban untuk membantu meningkatkan potensi masyarakat menjadi yang lebih maju lagi di masa depan karena seuah universitas tentunya membutuhkan masyarakat dan begitu pula sebaliknya. Masyarakat memerlukan perguruan tinggi untuk membantu dalam membangun atau menciptakan karakter generasi yang unggul (Syarifuddin, 2012).

Tiap-tiap kegiatan yang dilakukan mahasiswa KKN hendaknya memberi manfaat yang berguna bagi masyarakat dengan membantu menyelesaikan masalah dalam lingkungan masyarakat dan memberikan sebuah kesan yang mampu menjadi citra baik bagi mahasiswa. Adapun program yang akan dilakukan oleh mahasiswa KKN DR 187 yaitu sebagai berikut:

1. Pendidikan sangat tertinggal diakibat-kan oleh pandemi covid-19 sesuai dengan anjuran pemerintah bahwa semua pendidikan dilakukan dengan secara daring,, ditambah lagi perhatian yang diberikan oleh orangtua terhadap kepentingan belajar anak-anak di desa Air Merah masih sangat kurang, sehingga menyebabkan kurangnya pemahaman terhadap pembelajaran yang telah diberikan
2. Anak SD dan SMP desa Air Merah masih sangat kurang dalam wawasan agama. Seperti yang diketahui mahasiswa KKN yakni hafalan surah serta membaca Al-Qur'an sangat minim.

3. Anak SMP desa Air Merah masih sangat tertinggal dalam mengenal atau mengoperasikan computer atau TI.

4. Minat baca anak-anak desa Air Merah masih sangat kurang.

5. Kurangnya pemahaman terhadap kesehatan yang saat ini terjadi seperti wabah pandemi covid-19 yang mengharuskan untuk mentaati potokol kesehatan sesuai dengan anjuran pemerintah dan wajib vaksinisasi dengan tujuan meningkatkan kekebalan tubuh demi melawan serangan wabah covid-19.

Berdasarkan dari persoalan yang terjadi di desa Air Merah tersebut maka dari itu mahasiswa KKN sebagai sarana untuk membuka atau mengenalkan wawasan untuk membangun atau memajukan desa Air Merah. Adapun tujuan Mahasiswa KKN di desa Air Merah sebagai berikut ini:

1. Membantu pendidikan dengan melakukan bimbingan belajar gratis.

2. Membantu anak-anak desa Air Merah dalam belajar agama seperti halnya membaca Al-Qur'an ataupun Iqra' serta menghafal surah dalam AlQur'an.

3. Membantu anak-anak SMP desa Air Merah dalam hal mengoperasikan IT.

4. Membuka pojok baca masyarakat untuk mengenalkan dan memberi pemahaman bahwa pentingnya membaca.

5. Memberikan pemahaman terkait bagaimana mematuhi protokol kesehatan sesuai dengan yang dianjurkan.

Kali ini pengabdian yang dilakukan mahasiswa KKN di desa Air Merah yang 
merupakan dari 29 Mahasiswa yang melakukan penelitian menggunakan PAR selama metode yang digunakan Mahasiswa pada pengabdian masyarakat kali ini adalah PAR. Kata kunci dari PAR yakni Partisipasi, aksi dan research. Hal yang paling utama dalam PAR ini yaitu meneliti tentang masalah yang terjadi di desa Air Merah, agar mengetahui sebab akibat dari masalah tersebut. Selanjutnya apabila sudah mengetahui masalah yang terjadi maka tindakan selanjutnya yang harus dilakukan yakni mencari solusi dari masalah tersebut. Serta dapat diaplikasikan dengan tindakan nyata. Metode yang satu bulan tepatnya dari tanggal 10 Juli hingga 10 Agustus. Oleh sebab itu adapun terakhir yaitu melibatkan masyarakat berpartisipasi untuk menyelesaikan permasalahan yang terjadi di desa Air Merah tersebut.

\section{Metode}

Kali ini penelitian yang dilakukan dengan menggunkaan metode "PAR" atau Participatory Action Research yang merupakan istilah terpenting dalam melaksankan proses sosial masyarakat atau langkah kolektif dalam menemukan tujuan akhir atau kesimpulan mengenai " kasus atau peristiwa yang terjadi". Metode penelitian PAR tersebut adalah penelitian membutuhkan keterlibatan secara langsung setiap pihak atau stakeholders untuk membahas mengenai peristiwa yang terjadi yang memang terbukti kebenarannya atau bisa di sebut penelitian secara objektif. Proses dimana Mahasiswa melakukan perubahan atau perbaikan yang tentunya kepada arah yang baik, dengan demikian harus turut melakukan refleksi yang bersifat kritis dalam konteks seperti sejarah yang terjadi, kegiatan politik, budaya setempat serta perekonomian yang sedang di alami masyarakat desa Air Merah (Tim KKN, 2021: 37).

Participatory Action Research yaitu penelitian dengan model mencari titik penting untuk menghubungkan penelitian menuju tahap perubaha yang ingin dilakukan pada desa Air Merah. Adapun makna perubahan sosial disini yaitu yang menjelaskan bagaimana proses dalam meningkatkan potensi masyarakat untuk mewujudkan tiga bagian dari tolak ukur, yaitu sebuah komitmen yang harus dijalin dengan masyarakat, terciptanya sistem kepemimpinan yang baik dalam masyarakat, serta adanya ide baru untuk membangun desa Air Merah demi tujuan bersama. Model penelitian kali ini menunjukkan tahap penelitian untuk kepentingan bersama mencari bersama-sama solusi dari sebuah permasalahan yang terjadi di desa Air Merah (Rahmat \& Mirnawati, 2019: 3; Assingkily, 2021: 19-24).

Model Penelitian Participatory Action Research merupakan sebuah elemen dalam kehidupan yaitu berupa aksi. Yaitu aksi dalam menerapkan informasi yang di temukan serta aksi untuk solusi dari masalah-masalah yang terjadi. Semuanya di dasarkan pada hasil dari penelitian (Agus, 2013: 41).

\section{Hasil dan Pembahasan}

Kegiatan kali ini dibagi menjadi empat bidang yang tentunya menjadi bagian terpenting dan di dalamnya ada beberapa program dalam kegiatan yaitu di bagi menjadi beberapa bidang. Tepatnya kelompok kami di tempatkan di desa Air Merah, Labuhan Batu Selatan. Setelah pembekalan Online selesai kami langsung membuat perencanaan dan langsung terjun ke lapangan serta melakukan survey lokasi. Lalu kami pun melakukan acara pembukaan dan dari pihak universitas kepada perangkat didesa yang tepatnya pembukaan dilakukan 
di Kantor atau balai desa. Setelah sampai disana kami melakukan program pada kegiatan yang telah kami rencanakan. Berikut adalah beberapa program kejra yang kami lakukan:

\section{Bidang Pendidikan}

Pendidikan merupakan bidang yang paling penting untuk meningkatkan pengetahuan disekitar lingkungan desa Air Merah. Melihat begitu besarnya antusias masyarakat pada program dalam pendidikan, menjadi tugas istimewa bagi mahasiswa di KKN 187. Adapun program yang kami lakukan berjalan dengan baik tanpa ada hambatan. Semua ikut andil dalam melakukan program kegiatan pada bidang pendidikan yang kami jalankan. Dari tingkat anak-anak yang masih muda, tingkat menengah hingga orang tua desa Air Merah. Selain itu dalam hal ini, kami menaruh harapan yang besar kepada masyarakat baik dalam kalangan anak-anak, tingkat menengah dan yang lainnya untuk menerapkan ilmu pengetahuan yang sudah kami berikan. Dan kami sangat berharap kepada masyarakat untuk lebih meningkatkan semangat belajar untuk anakanak desa Air Merah. Dengan keadaan yang seperti saat ini kami mengupayakan proses belajar yang bersifat mendidik serta membantu membuka pola pikir pada anak SD dan SMP desa Air Merah ${ }^{1}$. Adapun bidang pendidikan meliputi beberapa bagian yaitu sebagai berikut:

\section{Kegiatan Bimbingan Belajar (Bimbel) Pada Siswa Di SD Dan siswa SMP}

Pada Program kegiatan tersebut dapat diartikan sebagai kegiatan yang dilakukan untuk anak SD dan SMP di Masjidmasjid. Dengan program kegiatan yang kami lakukan kami berharap hal ini mampu menjadi inspirasi kepada anak-anak desa Air Merah agar lebih giat lagi dalam belajar. Sebab di masa Covid-19 ini sangat

\footnotetext{
${ }^{1}$ Moh Yamin, Manajemen Mutu Kurikulum Pendidikan,(Yogyakarta: Diva Press, 2010), hal. 5-6.
}

dibutuhkan pelajaran tambahan diluar sekolah. Dengan diadakannya bimbingan belajar di Masjid-Masjid tentunya sangat membantu mengasah kembali pemikiran anak-anak SD dan SMP desa Air Merah. Yang mana mereka sudah lama tidak datang ke sekolah untuk belajar namun dengan di adakannya bimbingan belajar maka mereka dapat mengulang kembali pelajaran sekolah mereka.Serta di bimbingan belajar ini mereka akan mendapat wawasan baru dari Mahasiswa KKN Kelompok 187.

\section{Bidang Sains dan Teknologi Kegiatan Sosialisasi Pada Bidang IT}

Untuk menggali pengetahuan IT pada siswa SMP sekitaran desa Air Merah, terkhusus dalam mengenalkan IT dan Microsoft word dibagian dasar-dasarnya dan pengenalan perangkat-perangkat keras pada komputer atau laptop. Pengajaran berlangsung untuk anak-anak yang sasarannya adalah mulai murid-murid kelas 6 hingga pada angkatan SMP di desa Air Merah. Kegiatan ini di praktekkan langsung kepada anak-anak menggunakan laptop.

\section{Pojok Baca}

Pojok baca merupakan program kegiatan untuk anak SD tepatnya pada desa Air Merah di Masjid Baitul Muttaqin. Program ini diadakan guna untuk menambah minat baca para anak di desa Air Merah tersebut serta dapat membantu anak-anak dalam memilih buku yang tepat. Dalam kegiatan ini kami menyediakan beberapa buku yang cocok untuk anak-anak.

\section{Sosialisasi Pada Bidang.Sosial}

Adanya bidang sosial kali ini tentunya kami akan membantu dalam hal kemasyarakatan di Desa Air Merah seperti berikut ini.

\section{Gotong Royong}

Gotong royong ini ditunjukkan untuk membersihkan Masjid serta lingkungan 
sekitar masjid, Kantor Desa, dan Selokan. Kegiatan ini dilakukan bersama-sama dengan tujuan supaya fasilitas umum desa terawat dengan semestinya.

\section{Memberikan Sembako Pada Masyarakat yang Kurang Mampu}

KKN 187 memberikan sembako secara bersamaan dengan penyambutan hari raya Idul Adha, bertujuan untuk membantu masyarakat sekitar desa Air Merah dalam memenuhi kebutuhan mereka sehari-hari. Pembagian sembako ini diberikan kepada 19 KK (Kartu Keluarga). Dalam pembagian sembako ini memberikan gula, teh dan minyak. Dana ini didapatkan dari hasil pengumpulan dana kelompok kami.

\section{Bidang Agama}

Belajar di bidang agama tentunya sudah menjadi kewajiban umtuk setiap umat muslim, Walaupun kami Mahasiswa KKN 187 tidak memiliki ilmu pengetahuan agama yang cukup luas, akan tetapi kami tetap akan berusaha memberikan pengetahuan terbaik yang kami miliki dan membagikannya kepada anak-anak dan masyarakat disekitar desa air merah. Dalam bidang keagamaan ini diantaranya seperti wirid, takziah, seminar moderasi beragama dan belajar mengaji.

\section{Wirid}

Perwiridan yang diadakan didesa Air Merah mencakup dua macam yaitu, perwiridan untuk ibu-ibu dan perwiritan untuk bapak-bapak. Untuk perwiritan ibu-ibu sendiri diadakan setiap hari jum'at pada jam 13.30 WIB. Perwiridan bapak-bapak diadakan pada hari kamis malam pada jam 19.45 WIB. kelompok kami datang ke acara perwiridan dengan tujuan bersosialisasi tentang tujuan kami berada di desa tersebut. Takziah

Takziah merupakan kegiatan mengunjungi atau mengucapkan turut berduka cita atau istilah lainnya belasungkawa kepada keluarga yang terkena musibah, serta berdoa bersama untuk sang mayat, pelaksanaan takziah dilaksanakan setelah ba'da maghrib.

\section{Seminar Moderasi Beragama}

Seminar moderasi

beragama dilaksanakan secara virtual menggunakan zoom meet yang dilaksanakan tepatnya pada hari jum'at pukul 14.00 WIB. Tema yang kami angkat adalah "Peran Mahasiswa Dan Pemuda Dalam Kerukunan Umat Beragama" yang bertujuan untuk meningkatkan kerukunan antara agama satu dengan agama yang lainnya dengan meli-batkan para pemuda dan mahasiswa.

Selain seminar moderasi beragama mahasiwa KKN 187 juga melakukan wawancara kepada beberapa warga di desa Air Merah yang tentunya tetap mematuhi Protokol Kesehatan. Dari hasil wawancara tersebut dapat disimpulkan bahwa meskipun adanya perbedaan agama di desa Air Merah tapi hal ini tidak memutuskan silaturahmi antar warga, justru hal ini membuat para warga menjadi saling menghargai serta menghormati perbedaan yang ada. Contoh yang didapat dari hasil penelitian yaitu pada saat warga yg Muslim melakukan hajatan atau sebuah acara maka umat Nasrani juga hadir di dalamnya. Begitu pula sebaliknya jika yang mengadakan acara orang Nasrani maka warga yang Muslim juga akan hadir dan untuk menghargai serta menghormati warga yang Muslim orang Nasrani menyediakan konsumsi khusus muslim seperti nasi kotak atau catering dari orang muslim pula. Hal ini menunjukkan bahwa toleransi antar umat Muslim dan Nasrani di desa Air Merah terjalin sangat erat.

\section{Belajar Mengaji}

Membaca kitab suci adalah suatu tujuan untuk menjadikan kepribadian sebagai hamba Allah dan bertaqwa serta beriman kepada-Nya. Maka dari itu kelompok kami berinisiatif membuat kegiatan belajar mengaji bersama anak-anak disekitar desa Air Merah, kegiatan belajar mengaji dilaksanakan di tiga titik yaitu di Masjid A3, Masjid Al-Mukhtadin dan di 
Masjid Besar Air Merah. Tujuannya dibuat belajar mengaji bersama yaitu memberikan pemahaman kepada anak-anak bahwasannya Al-Qur'an itu penting bagi umat islam dan mengevaluasi anak-anak supaya tidak buta huruf Al-Qur'an. Belajar mengaji ini ditujukan kepada anak-anak mulai dari TK sampai SMP, kegiatan mengaji ini meliputi mengenal huruf hijaiyah, mengenal tajwid serta dalam menghafal surah pendek di dalam Al-Qur'an.

\section{Bidang Kesehatan}

Potensi masyarakat di bidang kesehatan yaitu proses di mana Masyarakat desa Air Merah mampu menyadarkan masyarakat untuk peduli kesehatan serta keinginan dalam memelihara serta meningkatkan kesehatan. Dalam rangka pencapaian mandiri dari masyarakat akan kesehatan dari masyarakat yang sudah menjadi kepentingan yang tidak boleh untuk di kesampingkan. Karna banyak masyarakat yang sekarang abai dengan kesehatannya. Maka benar apa yang dikatakan Rasulullah, dari Ibnu Abbas r.a beliau berkata: Nabi Muhammad Saw bersabda "Dua kenikmatan, kebanyakan manusia tertipu pada keduanya, yaitu, kesehatan dan waktu luang". [HR Bukhari, No,5993]. Bidang Kesehatan mengadakan sosialisasi prokes dan pentingnya vaksinasi, berpartisipasi dalam kegiatan posyandu lansia serta mengadakan bagi bagi masker kepada masyarakat desa Air Merah. Dengan diadakannya program program tersebut semoga masyarakat Air Merah memiliki keinginan dan mampu untuk menjaga kesehatan.

\section{Hasil Penelitian}

\section{Pada Bidang Pendidikan}

Pendidikan yaitu pemeran pertama dalam memajukan bangsa. Maka dari itu pendidikan harus lebih ditingkatkan lagi menjadi yang lebih baik dari sisi kuantitas serta kualitas. Pendidikan menjadi kebutuhan mutlak bagi manusia yang harus selama hidup di dunia ini. Tanpa adanya pendidikan maka manusia tidak akan mampu mengembangkan inspirasi dan citacita yang ingin mereka capai ${ }^{2}$. Dengan adanya bimbingan belajar geratis menjadikan Bertambahnya wawasan anakanak SD dan SMP di desa Air Merah. Mereka merasa sangat bersyukur telah mendapat ilmu yang tentunya sangat bermanfaat dari Mahasiswa KKN 187 sebab ilmu yang mereka dapatkan di sekolah sangat minim dikarenakan pandemi Covid-19. Dapat membantu serta meringankan pemikiran dan tenaga guru-guru disekolah SD dan SMP pada saat mengajar, serta membantu menciptakan komunikasi yang sangat baik dan silaturahmi yang baik pula terhadap anak-anak SD dan SMP. Menjadi motivasi bagi anak-anak SD dan SMP dengan adanya bimbingan belajar gratis di desa Air Merah sangat meningkatkan minat belajar mereka dengan metode belajar yang unik dan tentunya menarik perhatian anak-anak SD dan $\mathrm{SMP}^{3}$. Dengan adanya bimbingan belajar dari Mahasiswa KKN 187 dapat menambah pengalaman baru yang luar biasa bagi anak-anak SD dan SMP, seperti belajar di luar ruangan dengan Mahasiswa. Membantu mengingatkan kembali pelajaranpelajaran mereka yang sudah dipelajari sebelumnya. Seperti halnya pelajaran Matematika dan Pendidikan Agama Islam4.

\section{Pada Bidang Sains dan Teknologi}

Untuk mengimplementasikan teknologi di bidang informasi pada tingkat SMP bukanlah hal yang mudah. Yang paling utama menjadi perasalahan yaitu dana.

\footnotetext{
2 Ihsan, Fuad Dasar-dasar kependidikan, (Jakarta, Rineka Cipta, 2010), hal. 2

${ }^{3}$ B. Uno. Hamzah Teori Motivasi dan Pengukurannya Analisis di Bidang Pendidikan, (Jakarta: PT. Bumi Aksara 2011) ,hlm 94

${ }^{4}$ Hamalik. Oemar Proses Belajar Mengajar. Jakarta, (PT. Bumi Aksara, 2005). hlm 67
} 
Sebab untuk menggunakan IT membutuhkan modal atau biaya yang harus dibayar dengan nilai atau nominal yang cukup besar. Teknologi informasi sangat penting pada pendidikan anak SMP desa Air Merah, maka dari itu diperlukan tujuan dari manfaat belajar IT, Supaya mendapat kesan dan IImu yang berkah dalam mencapai fungsi dari pendidikan terkhusus lagi pada pihak atau perangkat yang memiliki wewenang ${ }^{5}$.

Adapun pentingnya teknologi informasi bagi pendidikan, yaitu

1. Dapat membantu proses pembelajaran melalui sarana pendukung pembelajaran.

2. Untuk Sarana atau alat membantu untuk memperoleh informasi.

3. Sebagai sumber pembelajaran yang sesuai dengan perkembangan zaman.

4. Untuk alat belajar yang tepat dalam menjelaskan materi pembelajaran anak SMP Desa Air Merah

5. meningkatkan kualitas pembelajaran yang tepat berdasarkan kebutuhan saat ini $^{6}$.

Beberapa manfaat dari kegiatan sosialisasi tentang IT untuk anak-anak desa Air Merah adalah anak-anak desa air merah wawasannya tentang teknologi menjadi bertambah,dan mereka merasa puas terhadap pengenalan Microsoft dan perangkat-perangkat keras nya sebab pengetahuan yang mereka peroleh sangat terbatas dikarenakan aturan dari pemerintahan dalam pelaksanaan pendidikan daring juga membantu anakanak untuk menjadi lebih kreatif dengan memberikan mereka kebebasan mewarnai gambar yang diberikan. Pojok baca mampu meningkatkan minat baca anak-anak ataupun masyarakat.

\footnotetext{
${ }^{5}$ Maesaroh Lubis, Kapita Selekta Pendidikan Islam, (Tasikmalaya:Edu Publisher, 2018), hlm. 59

${ }^{6}$ Dani Nur Saputra, dll, Landasan Pendidikan,

(Bandung : Media Sains Indonesia, 2021), hlm. 66
}

Dengan adanya pojok baca mereka mampu dengan mudah mencari informasi yang dibutuhkan.

\section{Pada Bidang Sosial}

Bidang sosial merupakan suatu bidang yang mempelajari tentang ilmu kehidupan bermasyarakat, Tujuan dari Bidang Sosial merupakan membantu memupuk jiwa sosialisasi Mahasiswa KKN 187 dengan Masyarakat desa Air Merah serta membantu menambahkan wawasan nyata bagi Mahasiswa KKN atas pelayanan dan pencapaian masyarakat. Pemberdayaan masyarakat merupakan kegiatan pengabdian yang sangat penting dan harus dilakukan dalam upaya untuk melepaskan masyarakat dari berbegai keterpurukan, ketertinggalan dan keterbelakangan?. Dalam bidang sosial ini kami membantu masyarakat dalam kegiatan seperti membersihkan masjid yang sekaligus meringankan tenaga najir masjid. Menerapkan kegiatan gotong royong di desa dapat membantu menjaga keawetan dan kebersihan fasilitas umum desa. Ikut merayakan Idul Adha, memeriahkan penyambutan Hari Raya Idul Adha dengan memberi bantuan berupa sembako kepada masyarakat sekitar desa yang kurang mampu.

\section{Pada Bidang Keagamaan}

Pada bidang ini agama merupakan sesuatu yang sudah direncanakan dan disusun rapi untuk mengaplikasikannya serta pemberdayaan ilmu agama bagi umat muslim di desa Air Merah, mengendalikan jati diri, pribadi yang lebih baik, mampu mencerdaskan diri, serta membantu memperbaiki akhlak bagi masyarakat desa

\footnotetext{
${ }^{7}$ A. Haris. Memahami Pendekatan Pemberdayaan Masyarakat,( Jupiter, 2014) 8(2)
} 
Air Merah ${ }^{8}$. Adanya kegiatan bidang agama ini berupaya menjadikan komunikasi yang baik dengan cara berpartisipasi dalam perwiridan dan takziah di lingkungan desa Air Merah. Membuat webinar tentang moderasi beragama dengan membawa tema yang tujuannya untuk meningkatkan kerukunan umat beragama terutama pada kalangan anak muda supaya lebih saling menghargai antar agama satu dengan agama lainnya.Anak-anak sekitar desa menjadi lebih paham pentingnya membaca Al-Quran dan bisa lebih mengenal huruf hijaiyah dan tajwid serta mengurangi buta Al-quran.

\section{Pada Bidang Kesehatan}

Hidup sehat, serta KKN DR 187 juga menyampaikan jangan terlalu takut dengan bahaya vaksinasi. Penyampaian atau pembahasan yang di sampaikan dapat diterima masyarakat desa Air Merah. Kegiatan ini berjalan dngan lancar, dan beberapa mahasiswa juga ikut membantu kegiatan posyandu Mahasiswa KKN DR 187 melakukan sosialisasi prokes tentang kesehatan, tujuan utamanya seperti masyarakat lansia yang telah mengikuti posyandu. Kali ini membahas tentang cara bagaimana lansia seperti menimbang, membantu antrian, dan memberikan obatobatan ${ }^{9}$.

Memberikan motivasi bagi diri sendiri untuk tetap menjaga kesehatan. Dengan adanya kami KKN di desa ini kami harapkan kami bisa membantu menambah wawasan masyarakat desa Air Merah supaya menyadarkan diri sendiri tentang pentingnya kesehatan $^{10}$. Dari kegiatan yang kami laksanakan dapat memberi manfaat kepada masyarakat seperti Para lansia menjadi tahu

\footnotetext{
${ }^{8}$ Undang-undang RI Nomor 20 tahun 2013, Sistem Pendidikan Nasional Pasal 1, ayat (1)

${ }^{9}$ Adisiswabto, W, Sistem Kesehatan, (Jakarta :

Pustaka Nasional, 2007) hlm. 22

${ }^{10}$ Yulda Arifada Aqsha, Analisis Sistem Kemitraan Dalam Program Imunisasi, (2015) hlm 74
}

bahwasanya vaksinasi itu tidak berbahaya apalagi bagi orang yang lanjut usia.

Para pengurus posyandu merasa terbantu adanya KKN DR 187 yang senantiasa menolong dengan ikhlas. Para lansia dapat konsultasi langsung dengan bidannya seputar penyakit yang dialami mereka.Para lansia menjadi lebih menjaga pola makan, dan kesehatan mereka dalam kehidupan sehari-hari.

\section{Simpulan}

Dapat disimpulkan hasil KKN DR 187 ialah seperti berikut ini:

1. Masih ada ditemukan orangtua/wali murid yang kurang peduli terhadap pendidikan anak di desa Air Merah, sehingga masih ditemukan anak-anak SD kelas 5 yang masih sulit untuk baca tulis.

2. Anak SD dan SMP di desa Air Merah masih sangat kurang dalam pelajaran agama seperti halnya membaca AlQur'an, menghafal surah, dan dalam hal ibadah mereka juga sangat kurang, serta hanya sedikit dari mereka yang mengetahui rukun iman dan rukun Islam.

3. Rendahnya pengetahuan anak SMP mengenai pengoperasian komputer, oleh sebab itu Mahasiswa KKN 187 membantu memberikan wawasan mengenai IT dan melakukan bimbingan serta praktek mengenai IT kepa-da Anak SMP di desa Air Merah.

4. Kurangnya pemahaman masyarakat mengenai pentingnya kesehatan di lingkungan sekitar. Apalagi pada masa Covid-19 ini, masih ditemukan beberapa warga yang tidak ikut vaksin.

5. Ditemukan kepedulian masyarakat yang tinggi dalam hal posyandu lansia dimana para lansia melakukan imunisasi, tensi dan melakukan konsultasi kepada pihak pustu.

6. Kurangnya kepedulian masyarakat dalam kebersihan lingkungan Masjid, karena di desa Air Merah najir Masjidnya tidak di 
tentukan. Hanya kesadaran masyarakat saja untuk membersihkannya. Hanya seorang warga yang sukarela untuk membersihkan Masjid.

7. Antusias masyarakat desa Air Merah untuk Mahasiswa KKN 187 sangat luar biasa. Diperlihatkan melalui keramahtamahan masyarakat dengan Mahasiswa. Dengan ikut melibatkan Mahasiswa dalam setiap kegiatan yang ada di desa Air Merah Seperti perwiridan dan takziyah.

8. Masyarakat desa Air Merah turut bahagia dan tentunya bersyukur atas pembagian sembako yang diberikan Mahasiswa KKN kepada beberapa warga yang kurang mampu.

\section{Daftar Pustaka}

[1] Afandi, Agus, et.al. (2013). Modul Participatory Action Research. Surabaya: LPPM UIN Sunan Ampel Surabaya.

[2] Aqsha, Yulda Arifada \& Thinni Nurul Rochmah. (2005). Analisis Sistem Kemitraan dalam Program Imunisasi Berdasarkan Peran Perangkat Desa, Bidan Desa, dan Masyarakat. JAKI: Jurnal Administrasi Kesehatan Indonesia, 3(2). https://www.ejournal.unair.ac.id/JAKI/article/view/1867

[3] Hamalik, Oemar. (2007). Proses Belajar Mengajar. Bandung: Bumi Aksara.
[4] Haris, Andi. (2014). Memahami Pendekatan Pemberdayaan Masyarakat. Jupiter, 13(2). https://journal.unhas.ac.id/index.php/jup iter/article/view/1647.

[5] Ihsan, Fuad. (2003). Dasar-dasar Pendidikan. Jakarta: Renika Cipta.

[6] Lubis, Maesaroh. (2018). Kapita Selekta Pendidikan Islam. Tasikmalaya: Edu Publisher.

[7] Rahmat Abdul \& Mira Mirnawati. (2020). Metode Participatory Action Research dalam Pemberdayaan Masyarakat. Jurnal Aksara: Jurnal Ilmu Pendidikan Nonformal, 6(1). http://ejurnal.pps.ung.ac.id/index.php/Ak sara/article/view/198.

[8] Saputra, Dani Nur. (2021). Landasan Pendidikan. Bandung: Alfabeta.

[9] Uno, Hamzah B. (2011). Teori Motivasi dan Pengukurannya: Analisis di Bidang Pendidikan. Jakarta: PT. Bumi Aksara.

[10] Tim KKN. (2021). Panduan KKN Metode Penelitian pada KKN. Medan: UIN Sumatera Utara Medan.

[11] W., Adisiswabto. (2007). Sistem Kesehatan. Jakarta: Pustaka Kesehatan.

[12] Yamin, Moh. (2010). Manajemen Mutu Kurikulum Pendidikan. Yogyakarta: Diva Press. 